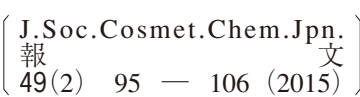

\title{
主成分分析をベースとした統計的顔画像解析による 透明感の定量化手法*
}

\author{
五十嵐崇訓 ${ }^{* * * * * *}$, 守口順二***, 直木 隆 明***, \\ 瀬尾昌孝***, 陳 延偉*** \\ 花王株式会社 スキンケア研究所**, \\ 立命館大学 大学院 情報理工学研究科***
}

\begin{abstract}
本論文では，透明感を定量化するための顔画像評価法を提案する。透明感を含む質感・印象の従来 的な評価法は, 顔のある部分の肌を評価対象として代表させ, その肌の光学特性や画像特徵量を解析 するアプローチがほとんどであった。しかし，質感·印象の多くは，顔のある特定の部分からではな く, 顔全体や顔の様々な部分の特徵から想起されると考えられる。よって, 従来法にかわる全顔画像 を解析対象にした新たな評価法が期待される。以上の背景から, 本研究では顔画像の特徵抽出に優れ る統計的画像解析法を応用した顔テクスチャ特徵の定量化法を新たに開発し，己れを透明感評価に適 用した。まず統計的画像解析を行う際に必要亡なる学習用データとして, 顔形状がすべて統一されテ クスチャのみが異なる形状正規化顔画像データベースを構築した。次に, このデータベースに対して 主成分分析を実施し，顔テクスチャの特徵を表す固有空間を算出した。最後に，この固有空間におけ るテクスチャの表現特性を利用して, 顔のテクスチャ特徵量を定量化できる「固有差分累積法」を開 発し, 透明感評価に適用した。目視による透明感評価との比較から, 本法が透明感を精度よく推定で きることが確認された。
\end{abstract}

\section{1. 緒言}

顔やその肌はわれわれにとって最も身近な認知の対象 である11。それゆえ，われわれはその質感・印象に対し て非常に敏感であり ${ }^{2)}$ ，これらをよりよい状態にしたい と考えている。このような要望から, 顔や肌の質感・印 象を改善, 演出するための有効なツールとして化粧品が 広く利用されている。例えば，ファンデーションに代表 されるベースメイクアップ製品は，顔やその肌の質感 · 印象を即時的に改善，演出する有効なツールである3)。 また，化粧水や美容液といったスキンケア製品は，これ を連用して使用することで保湿や美白等のスキンケア効

*2014.8.4 受付，2015.1.16 採用

**\%131-8501 東京都墨田区文花 2-1-3:2-1-3, Bunka, Sumida-ku, Tokyo 131-8501, Japan

*** 干 525-8577 草津市野路東 1-1-1 : 1-1-1, Noji-Higashi, Kusatsu 525-8577, Japan
果により肌状態の改善を促す有効なッールであり ${ }^{3)}$ ，こ のような肌状態の改善は, 結果として肌や顔の質感・印 象の改善につながることが期待できる。以上の例のよう に，化粧品には，顔やその肌の演出，状態改善を通し て，より好ましい質感・印象を実現することが期待され ている。このような背景から，化粧品の設計・開発やそ の効果評価を目的として, 質感・印象を客観的に定量化 するための手法がこれまでにも提案されてきた ${ }^{4), 5)}$ 。

これらの従来的な評価法では，例えば消費者からの ニーズが高い透明感などの定量化を目的として，主に光

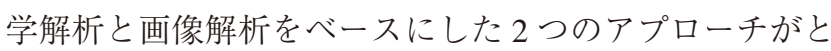
られている゙)。ここで，光学解析を用いたアプローチ は，質感・印象を肌の反射や透過といった光学特性の観 点から評価するものである ${ }^{5)}$ 。一方，画像解析を用いた アプローチは, 解析対象とする肌画像を取得し, その質 感・印象を画像特徵量の観点から評価するものであ る4),5)。いずれのアプローチに扔いても従来は，顔のあ る特定部分の肌（例えば㚘部の肌）を代表させて，その 
光学特性または画像特徵量を定量化することが一般的で あった。しかし，われわれは顔を観察する際，様々な部 位にその視線を移動させているので ${ }^{\circ}$ ，肌や顔の質感・ 印象を顔のある特定部分のみからではなく, 顔全体や顔 の様々な部分の観察から想起していると考えられる7》。 よって, 顔のある特定部分を解析対象として代表させる 従来的アプローチは, 顔から想起する質感・印象の評価 を行うためには解析対象が限定されており課題がある。 以上から，化粧品開発への応用を目的とした質感・印象 評価研究を今後発展させるにあたっては, 顔全体を解析 対象とした新たな評価法の提案が求められる。

顔から想起される質感・印象は, 顔の形状とテクスチャ* の影響を強く受けていることが指摘されている ${ }^{8) \sim 10)}$ 。 このうち，化粧品は形状を制御することはできず，一 方，テクスチャを改善することに効果を示す。よって， 化粧品開発を目的とした顔の質感・印象評価法を開発す る際には, 顔のテクスチヤにのみ評価対象を絞った解析 の実現が求められる。これまでに提案されたテクスチャ に対象を絞った質感・印象に関する評価手法は，ほとん どが顔の特定部分を対象にしたものであり ${ }^{4), 5), 9), 10)}$, 顔 画像のテクスチャを扱った解析法については, 光沢, て かりの評価を扱った報告がわずかにあるのみで ${ }^{11,12)}$, 解析手法のバリエーションや評価対象とする質感・印象 はいまだに限定されている。そのため, 顔の質感・印象 を定量評価する際に利用可能な, より一般化した新たな 顔テクスチャ解析法の開発が期待される。

以上の背景から, 本研究の目的は, 化粧品開発を目的 とした質感・印象評価法として

（1）全顔画像を解析対象にした,

（2）顔テクスチャを選択的に定量化できる

新たな画像解析法を提案することである。このような全 顔画像のテクスチャを直接的に定量評価する際の有用な アプローチとして, 主成分分析 (principal component analysis：PCA）や独立成分分析（independent component analysis：ICA）などの統計的手法をべースにした統計的 顔画像解析法が挙げられる ${ }^{13)}$ 。統計的顔画像解析法は, 顔認識技術 ${ }^{14)}$ を目的としてその技術が発展し, 最近では この技術をべースにして, 顔の質感・印象評価への応用 が研究されている 15) 17)。本研究では, PCAをべースと した統計的顔画像解析法である Eigenface 法 ${ }^{18)}$ の機能特

\footnotetext{
*本報でいう形状とは, 3 次元的な顔の形態に関わるものとし, 例えば，目・鼻等の位置，形態や顔の輪郭形状などを指す。 また，テクスチャとは，肌の不均一性または，明るさ，色の 空間分布に関わるものとし，例えば，陰影，光沢や，毛穴. 色むら等の肌の欠点のような微細な肌の不均一性とする。
}

性を利用して顔テクスチャの特徵量を定量化し, 質感・ 印象を評価する新たな手法を提案する。ここで，本論文 では, 評価対象となる具体的な質感・印象として, 化粧 品の消費者からのニーズが高い透明感 ${ }^{4)}$ (19)を取り上げ る。透明感は主に視覚的な要因に由来する感覚量と考え られ20), 透明感のレベルには複数の肌の外観特徵が寄与 すると考えられる4),5, 19),20)。この中で肌の均一性などに 関わるテクスチャの状態は, 透明感に強く寄与をする重 要な因子であることが指摘されている(4),5),20) 222)。本研 究では, 透明感を感じる顔画像と評価対象となる顔画像 に対して, 顔のテクスチヤの相違度を提案法により定量 化することで, 透明感のレベルが精度よく評価できる可 能性を示す。本報では, 以上の具体的な結果を報告し, さらに提案法の透明感評価に扔ける有用性と課題につい て考察する。

\section{2. 方法}

\section{1. 統計的顔画像解析のための学習用顔画像データ ベースの構築}

\subsection{1. 顔画像データベースに求められる要件}

本研究が提案する解析法は, PCAをべースとして統 計的に顔テクスチヤの特徵量を抽出することを目標とす る。この解析の実行に際しては, 統計学習用データとし て多量の顔画像（顔画像データベース）を事前に用意す る必要がある。ここで, ベースメイクアップやスキンケ アなどの化粧品開発を目的とした評価に用いる統計学習 用の顔画像データベースには，すでに報告・提供されて いる従来的な顔画像データベース ${ }^{23}$ にはない次の 3 点の 特徵が求められる。

A）ベースメイクアップを塗布する前後の顔画像から構 成されること

B）年齢の違いなど幅広いバリエーションの顔画像から 構成されること

C) データベース中の全顔の形状が統一 (正規化) され ていること

まず，A）について，これを満足することにより，スキ ンケア (素顔) と, ベースメイクアップ (化粧顔) の両 方の評価を視野に入れた研究が可能となる。この際, こ れらの評価を効果的に行うためには，同一人物の化粰前 後の顔画像セットをデータベースに含んでいることが望 ましい。次にB）について, 統計的解析においてはデー タベースを構成するデータ群に偏りがないことが望まし い。本研究は, 化粧品開発を想定したものであるため, データベースを構成する顔画像はすべて女性であるべき だが, 一方で, 様々な女性（年齢, 肌状態の違いなど） 
の素顔, 化粧顔画像がデータベース中に含まれているこ とが望ましい。最後にC）について，前章で論じたよう に, 化粧品は顔の輪郭や, 目, 鼻の形などの顔形状を制 御する作用はなく，顔テクスチャのみが制御できる。 よって，データベース中の顔画像の形状バリエーション は化粧品研究を目的とした場合は不要な情報となる。 データベース中の顔画像について，これらの形状を事前 に統一（正規化）することで，顔テクスチャに特化した 評価が実現できる。

\subsection{2. データベース用顔画像の取得装置}

上記 A）～C）を満たす独自の化粧顔画像データベース を構築するため，独自開発した Multi-angle Image Capturing System (MICS, Fig.-1) 24)により多量の顔画像を取得 した。MICS は，20台の高画質 CCD カメラと 40 台の照 明が顔を取り囲むように球面座標系にそってそれぞれが $15^{\circ}$ 置きに配置された構成となっており，これにより， 様々な照明条件下における顔画像を多視点で撮影可能で ある。また, MICS は高画質 CCD カメラ（RGB カラー, 約 $6 \mathrm{M}$ ピクセル ; 横 3008 ピクセル×縦 2000 ピクセル) を採用することで，全顔画像を取得しながらも，その肌 の毛穴，色むらといったテクスチャが取得できる。これ により，顔全体をとらえながら，様々な顔部位のテクス チャに関する評価が実現できる。

\subsubsection{Multi-angle View Illumination Cosmetic Facial Image Database の開発}

MICS を用いて，まず前述のA)，B）の要件を満たす 顔画像データベース（Multi-angle View Illumination Cosmetic Facial Image Database：MaVIC）の構築を行った。 MaVIC は, 40 タイプの照明条件下 20 方位から撮影さ れた顔画像から成る多視点・多照明顔画像データベース である（Fig.-2には，代表的な角度における多視点・多 照明顔画像の例を示す)。MaVICには 10 代〜70 代の日
本人女性のベ 420 名のベースメイクアップ塗布前後の顔 画像が含まれており，特に，100名分の顔画像は，同一 人物の化粧前後の顔画像のセットとなっている ${ }^{24)}$ 。本研 究では，その評価対象が正面から照明された正面顔画像 であるため，以下の議論ではすべて MaVIC 中の正面顔 画像を用いた検討を示す。

\subsection{4. データベースを構成する顔画像の形状正規化}

構築した MaVICから，化粧前後の顔画像セット 100 名を含む，272枚の顔画像を選択し，以下の $1 \sim 3$ の手 順で選択顔画像を平均顔形状にすべて正規化することで (Fig.-3)，前述の要件 C) を満たす形状正規化顔画像デー タベースを構築した。

1. 顔画像の眉, 目, 鼻, 口, 輪郭から 114 点の特徵点 を手動で取得

2. 特徵点を線でつなぎ，三角形に分割することで形状 変化領域を指定

3. Piece-wise linear affine のワーピング25)を用いて指定 した形状変化領域を変形させることで，すべての顔 画像を平均顔形状に変換（正規化）

上記操作により，顔の輪郭形状や，眉，目，鼻，口など の部位の位置が統一化されたテクスチャのみ異なる顔画 像データベースを構築することができた。

以上 2.1.2〜2.1.4の作業により，2.1.1で示した化粧品 評価用データベースの要件 A）～C）すべてを満たす独自 の顔画像データベースが構築された。なお，計算負荷を 考慮して，以下の検討では画像サイズを縮小したものを 用いた。具体的には，顔の局所的テクスチャ（毛穴，し みそばかすなど）が画像中で確認できる画像サイズとし て，横 280 ピクセル，縦 360 ピクセルとした。また，顔 画像を構成する RGBの色成分のうち，G（緑：中波長 帯に相当）が顔やその肌のテクスチャ認知において最も 寄与が大きいことから ${ }^{26)}$ ，以下 $\mathrm{G}$ 成分に対して解析を

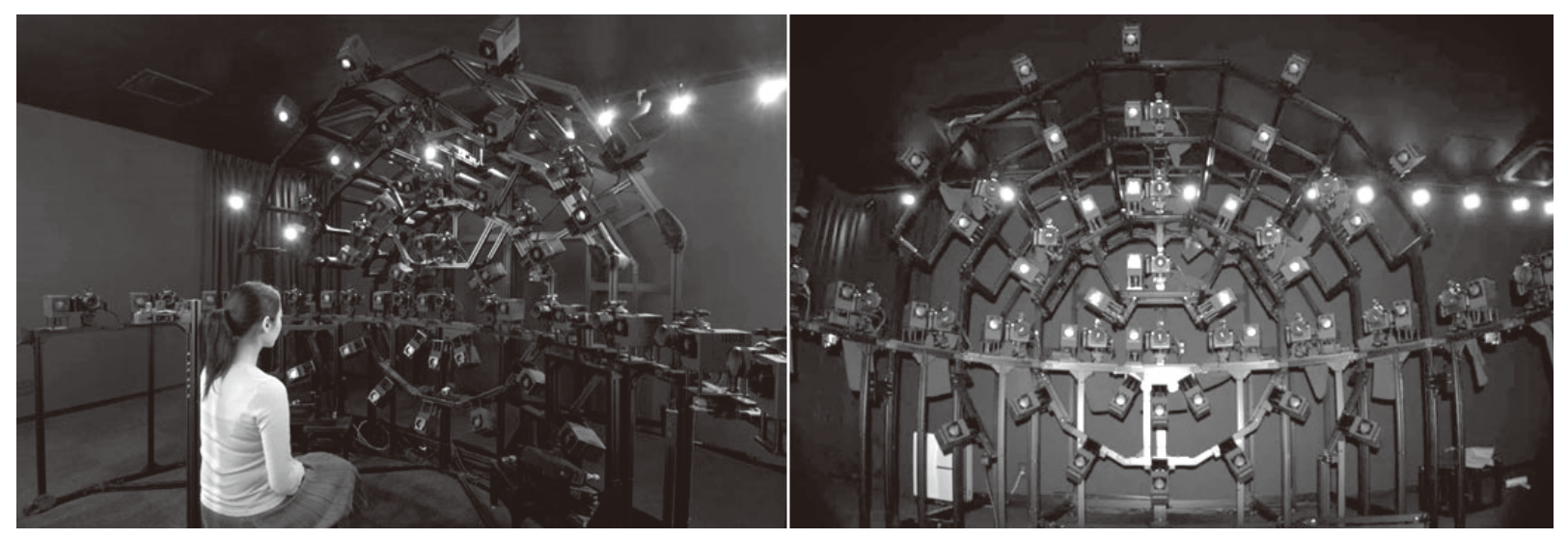

Fig.-1 Multi-angle image capturing system for acquiring facial images of a database. 


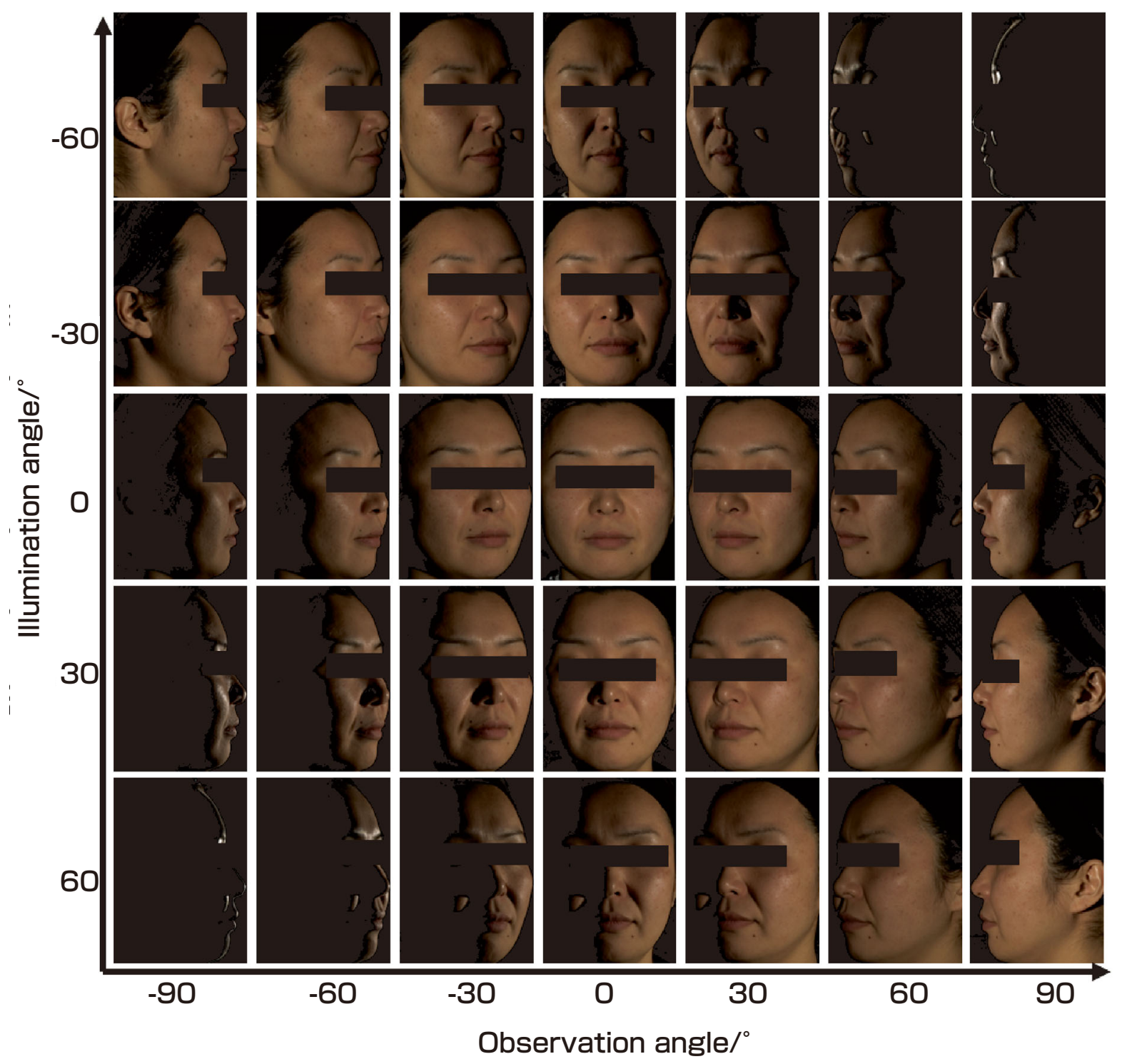

Fig.-2 Example of multi-angle facial images in MaVIC.

適用した。

\subsection{PCA をベースとした顔テクスチャ解析法の 開発}

\subsubsection{PCA による顔テクスチャの特徵抽出}

PCA をベースにして顔画像の特徵量を定量的に記述 できる Eigenface 法 $^{18)}$ を用いることで, 前章で構築した 形状正規化顔画像データベースから顔テクスチャの特徵 ベクトル（固有基底関数）を算出した。評価対象となる 顔画像を $\mathbf{x}$ とすると, $\mathbf{x}$ は構築顔画像データベースを学 習データとしてPCAにより算出される固有空間におい $\tau$,

$$
\mathbf{x}=\mathbf{m}+y_{1} \mathbf{v}_{1}+\cdots+y_{n} \mathbf{v}_{n}
$$

と記述される。ここで, $\mathbf{m}$ はデータベース中の顔画像 の平均べクトル (平均顔), $\mathbf{v}_{\mathrm{i}}$ は固有基底関数, $y_{\mathrm{i}}$ はそ
の係数であり, $n$ は基底関数の総数（本研究では $n=$ 272）を示す。ここで本研究の場合, データベース中の 全顔画像の形状は正規化されておりテクスチャのみ異な るので， $\mathbf{v}_{\mathrm{i}}$ は顔画像のテクスチャ特徴を選択的に表現し ている。よって, 式(1)において, 顔テクスチャの違い は係数 $y_{\mathrm{i}}$ の違いとして定量的に表現される。

固有基底関数 $\mathbf{v}_{\mathrm{i}}$ は, その固有值の大きさに従って, およそ大域的なテクスチャから局所的なテクスチャを表 現する順に序列する傾向がある ${ }^{13)}$ 。Fig.-4 は構築データ ベースから算出した固有基底関数 $\mathbf{v}_{\mathrm{i}}\left(\mathbf{v}_{\mathrm{i}}\right.$ は 2 次元情報を 持つので画像として表現され，これを固有顔とよぶ）を 固有值の大きいものから小さいものの順番に並べたもの の抜粋である。この図からわかるように, 固有值の大き い固有顔（低次の基底）では, 顔のより大域的（全体的 な）テクスチャが表現されている。一方, 固有值が小さ 


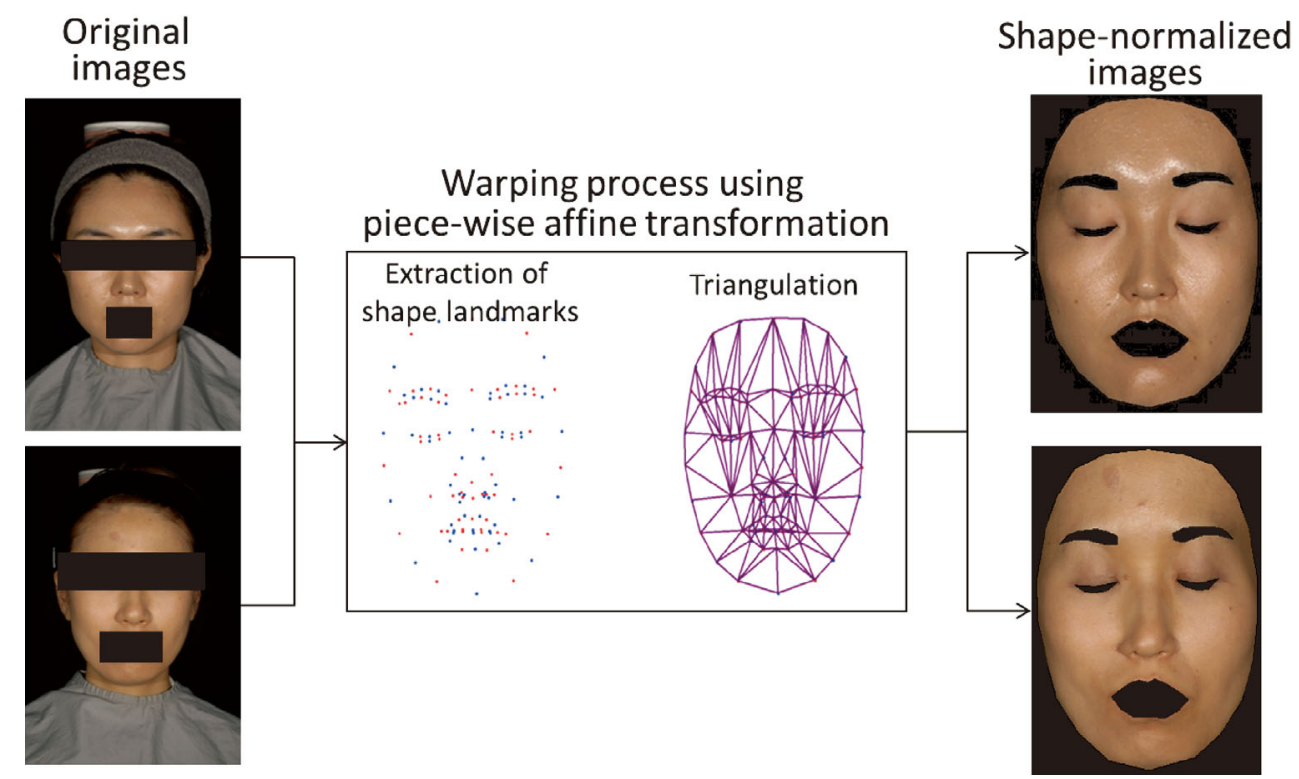

Fig. -3 Computation process for the synthesis of shape-normalized facial images.
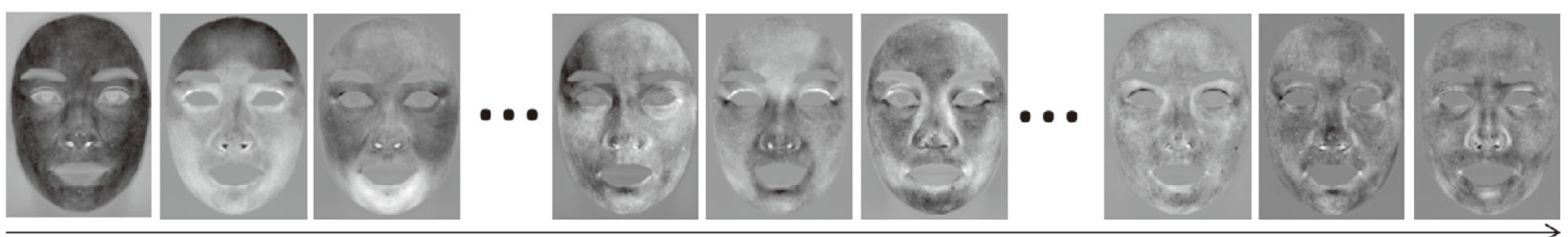

Larger eigen value

Smaller eigen value

(global texture)

(local texture)

Fig. -4 Typical basis of the eigen vectors (eigenfaces) arranged with the descending order of the eigen value from the left to the right: eigenfaces with greater eigen values give global facial texture; and eigenfaces with smaller eigen values give local facial texture.

(a)

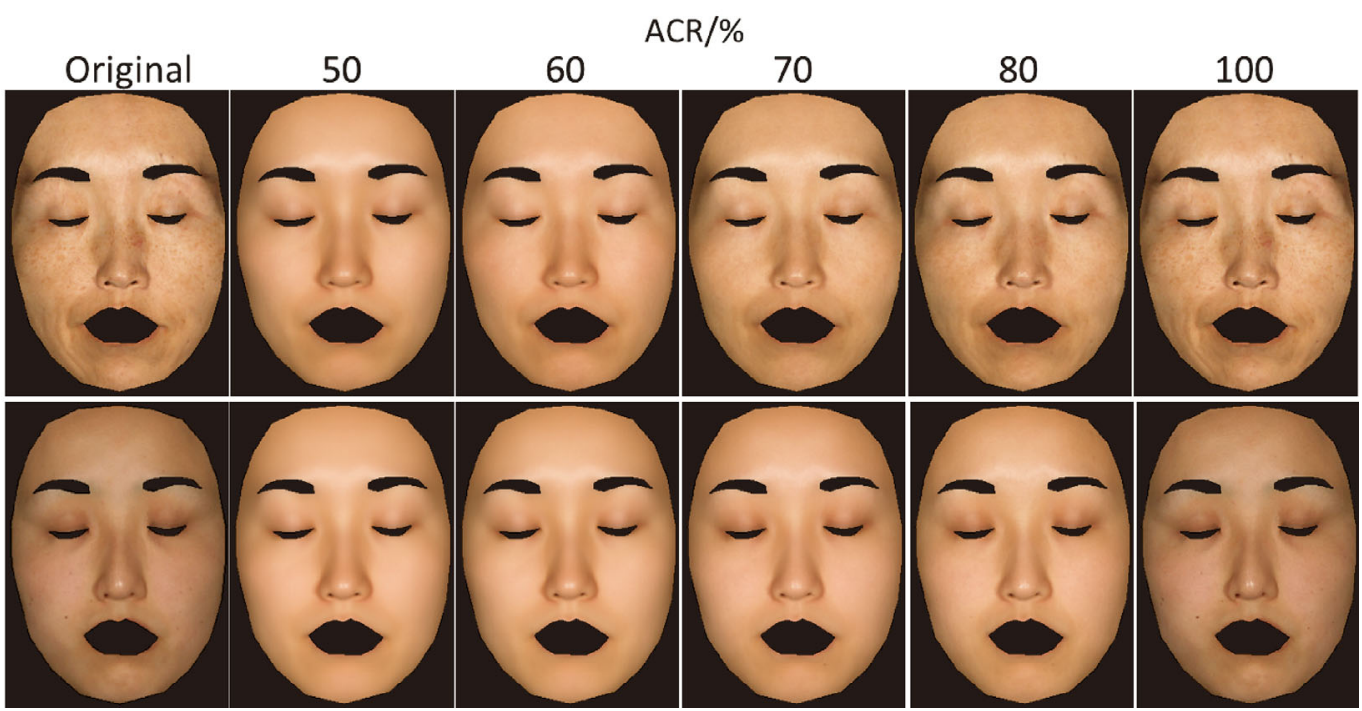

Fig. -5 Examples of reconstructed facial images.

(a) an aged face (less perceived translucency), and (b) a face with flawless skin (more perceived translucency). 
い固有顔（高次の基底）になると，より局所的（微細な） テクスチャが表現される傾向にあることが確認できる。

このような固有空間の持つテクスチャ特性に由来し て, 式(1)に従って顔画像を再構成した場合, 再構成の 度合を示す累積寄与率（accumulated cover ratio：ACR）が 高まるにつれて, 個々人の顔の質感・印象に寄与する顔 テクスチャの特徵が徐々に再現される。例えばFig. -5 (a)，(b) は，透明感印象の程度が異なる顔を再構成し た過程の顔画像であるが, ACRの低い顔画像（より固 有值の大きい低次の基底関数でのみ再構成した顔画像） では，Fig. -5(a)，(b) ともに毛穴や色むらといった透明 感を阻害すると予想される肌の欠点などの局所的テクス チャの情報が欠落している。一方，ACRの高い顔画像 (より固有值の小さい高次の基底関数もあわせて用いて 再構成した顔画像) では, Fig.-5(a)において, 肌の欠 点に由来するテクスチャ情報が表現され（およそ ACR $=70 \%$ 以上でこれらのテクスチャの再構成が確認され る), Fig. -5 (b) との透明感の違いも明確になってくる。 また, Fig. -5 の各顔の再構成画像の比較から, ACR が 高まり局所的なテクスチャが表現されたほうが，各顔の 質感・印象の違いがはっきりと現れることもわかる。以 上の結果は, 固有空間における基底関数の序列特徴を利 用し, 特に一定の ACR 以上の高次の基底関数が作り出 すテクスチャに着目することで，透明感の阻害要因とな るテクスチャの特徵量が定量化できる可能性を示す。

\subsection{2. 再構成顔画像を用いた顔テクスチャの定量化}

以上示した固有空間における顔テクスチャの表現特性 を利用して, 顔画像から透明感を定量化することを考え る。これを実現するためには，まず再構成顔画像を用い て顔テクスチャを定量化する手法を開発することが必要 である。個々人の特徴を表す顔テクスチャを定量化する には, 平均顔（個々人に由来する顔テクスチャがない顔 画像）と，ACR 100\%の再構成顔画像との差分画像を取 得し，この差分画像のテクスチャを数值化すればよい。 しかし現実的には, Fig. $-5(\mathrm{a})$, (b) の例からもわかるよ うに, 再構成顔画像は ACR が増大するにつれて, その 顔画像の全体的な輝度（明るさ）に変化が生じることが しばしばみられる。この輝度のズレのために, 単純に平 均顔と ACR $100 \%$ の再構成顔画像間の差分画像から顔 テクスチャを抽出し定量化することは困難である。

この課題を解決するために，本研究では以下の計算ス テップに従って顔テクスチャの特徴量を定量化した (Fig. -6$)$ 。

Step 1 評価したい顔画像について, ACR を少しずつ変 化させた再構成顔画像を生成する
Step 2 ACR が隣接する再構成顔画像間の差分画像を取 得する

Step 3 Step 2 において取得した差分画像の分散值を算 出し, 各差分画像の定量值（差分量）とする

Step 4 Step 3 で取得した差分量を総和し, 評価顔画像 のテクスチャ特徵量とする

Step1, 2 において, ACRの変化率 (刻み幅) は，これ を小さくするほど再構成画像間の輝度のズレを抑制でき る。しかし，ACRの変化率を小さくしすぎると，再構 成顔画像間の差分量が少なくなり，これを定量的に検出 することが難しくなる。本研究では，ACRの刻み幅が 3\%を下回ると差分量の検出が難しくなったことから， 刻み幅を $3 \%$ として検討を進めた。

Step 3 について, 隣接する再構成顔画像間の差分画像 を算出すると, 差分画像の各ピクセルは正または負の值 を有する。このうち正の值を示すピクセル群は，再構成 に伴い，例えば光沢のような顔の局所面における平均值 よりも明るい值で構成されるテクスチャを作り出す要素 と予想される。一方，負の值を示すピクセル群は，例え ば毛穴や色むらといった肌の欠点のように，顔の局所面 における平均值よりも暗い值で構成されるテクスチャを 作り出す要素と予想される。実際，算出された正と負の 差分画像をそれぞれ累積した画像（差分累積画像，Fig.7）において，正の差分累積画像では，光沢部分など顔 の各局所面において平均よりも明るい部分が選択抽出さ れている。一方，負の差分累積画像では，毛穴，色むら など，各局所面において平均よりも暗い部分が抽出され ている。このような正と負の差分（それぞれ正差分，負 差分とよぶ）に由来するテクスチャは，顔の質感・印象 において異なる寄与を示す可能性がある。そこで本研究 では，正差分と負差分を分離して定量化することにし た。

最後にStep 4 で, Step 3 において算出した正, 負の差 分画像の分散值を累積する。ACR が $i$ \%とこれに隣接 する $(i+3) \%$ の再構成画像間の正と負の差分画像から 求まる分散值をそれぞれ，var $(i)$ ，var $-(i)$ と表記した とき，正，負それぞれの累積量 $V_{\text {total }+}, V_{\text {total }}$ は，

$$
\begin{aligned}
& V_{\text {total }+}=\left|\sum v a r_{+}(i)\right| \\
& V_{\text {total }-}=\left|\sum v a r_{-}(i)\right|
\end{aligned}
$$

として算出される。よって, 正負を共に加味した全累積 量 $V_{\text {total }}$ は

$$
V_{\text {total }}=\sqrt{V_{\text {total }+}^{2}+V_{\text {total }-}^{2}}
$$




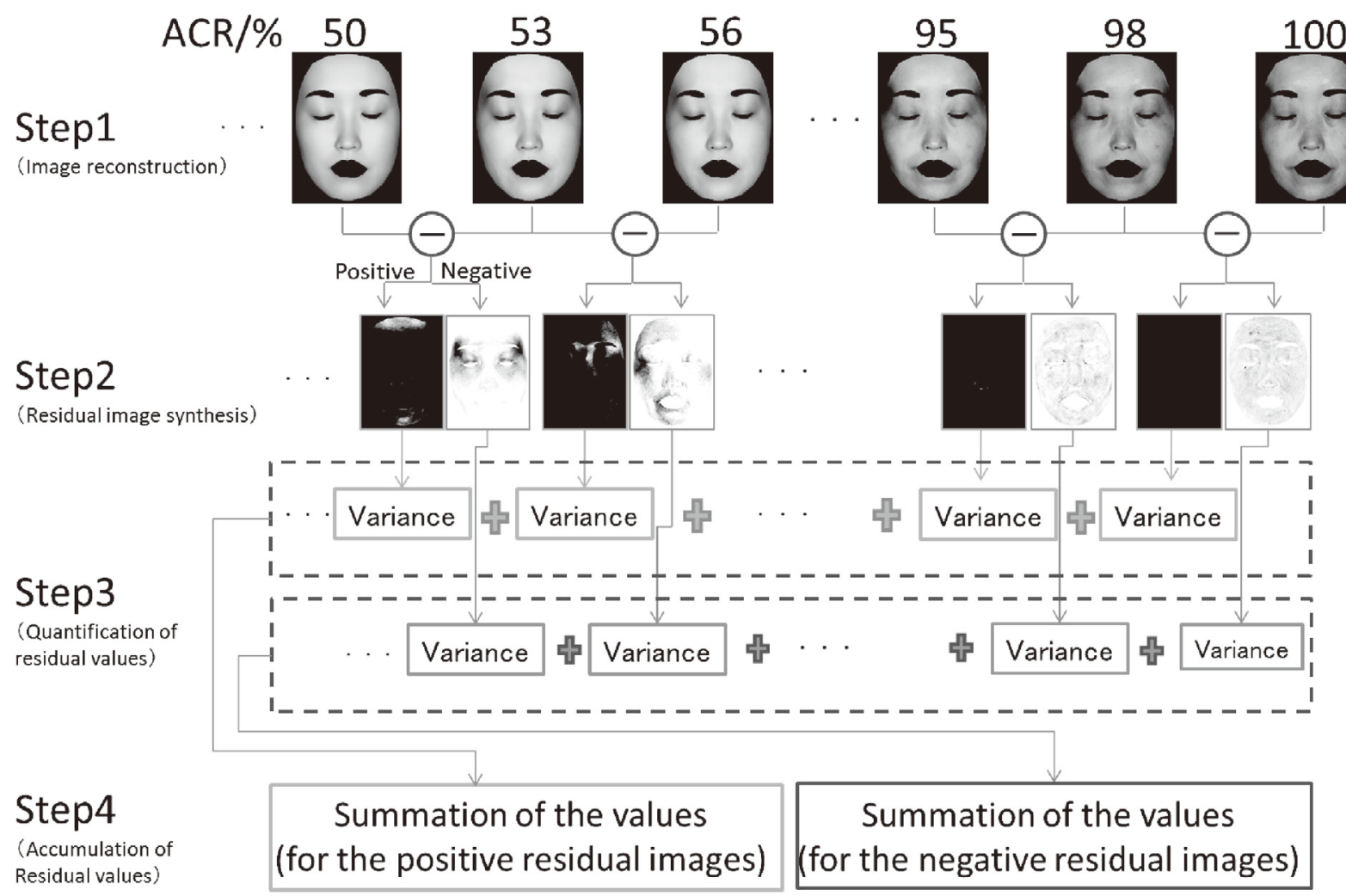

Fig.-6 Computation process for the quantification of facial texture ("Eigen residual accumulation method").

として算出される。以上のような固有空間の特性を利用 して，テクスチャ特徵量を差分量の総和として算出する 手法を，本研究では「固有差分累積法」(Eigen Residual Accumulation Method）とよぶ。

\subsection{3. 透明感に関わるテクスチャ特徵量の定量化}

次に，特に本研究が対象とする透明感に関わるテクス チャ特徵量を特定し，これを固有差分累積法で定量化す ることを考える。2.2.1で論じたように，再構成した顔 画像には ACR が高まるほど，個々人の顔の質感・印象 の決定に寄与するテクスチャが再現される。ここで，透 明感の個人差は, どの ACR 以上からの差分顔画像を解 析対象とすることで評価できるのか決定するため，化粧 品評価研究に従事する 3 名の評価者により主観的に透明 感が高いと感じられた 5 名の顔画像（Fig.-8）をデー夕 ベースから選択し，前述のStep1〜4に従って算出した 正・負差分量の累積值の ACR 值に対する変化を比較し た。その結果, 興味深いことに, ACR68\%を境界值と して選定し，このACR68\%に扔ける正・負差分量を基 準として（すなわち０として）98％までの変化パターン を比較すると， 5 名の示す曲線がほぼ一致することがわ かった（Fig.-9）。また，これら 5 名の平均值のパター ンは, これら 5 名とは別の, 美肌を有した透明感を感じ る顔 (Fig.-10 (a)) の変化パターンとよく一致し, 一方,
透明感が低く感じられた加齢印象の強い顔 (Fig.-10 (b)) の変化パターンとは大きく異なる傾向にあった（Fig.11)。これは，ACR 68\%から ACR 98\%に打ける差分量 を定量化することにより，透明感のレベルが定量化でき る可能性を示唆する。

ACR 68\%から 98\%に打ける差分量は，式(2)，（3）を ベースにして，次式として記述される。

$$
\begin{aligned}
& V_{+}=\left|\sum_{i=68}^{95} \operatorname{var}_{+}(i)\right| \\
& V_{-}=\mid \sum_{i=68}^{95} \text { var }_{-}(i) \mid
\end{aligned}
$$

ここで，式(5)，(6)を用いて算出した透明感の高い 5 名 の $V_{+}, V_{-}$の平均值を $V_{+ \text {ideal }}, V_{-i d e a l}$ とし, 評価したい顔 の $V_{+}, V_{-}$を $V_{+e v a l}, V_{- \text {eval }}$ とすると, 評価顔と透明感顔 の差異 $\Delta V_{+}, \Delta V_{-}$はそれぞれ次式により算出される。

$$
\begin{aligned}
& \Delta V_{+}=\left|V_{+ \text {eval }}-V_{+ \text {ideal }}\right| \\
& \Delta V_{-}=\left|V_{- \text {eval }}-V_{- \text {ideal }}\right|
\end{aligned}
$$

以上から, 本研究では式(7), (8)を用いて, 透明感レベ ル $\Delta V$ を式(9)として定義した。

$$
\Delta V=\sqrt{\Delta V_{+}^{2}+\Delta V_{-}^{2}}
$$



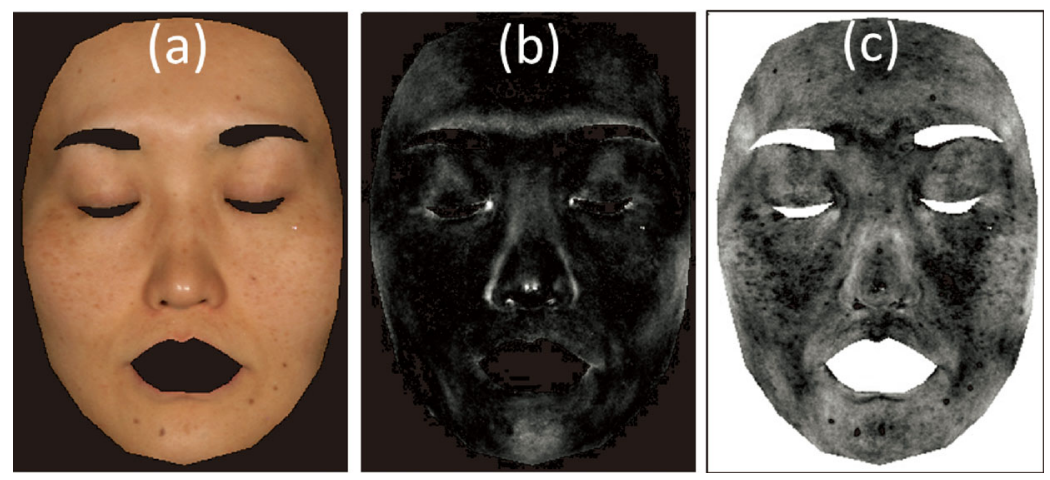

Fig. -7 Example of computed images

(a) original facial image, (b) accumulated residual image (residual images with positive differences), and (c) accumulated residual image (residual images with negative differences).
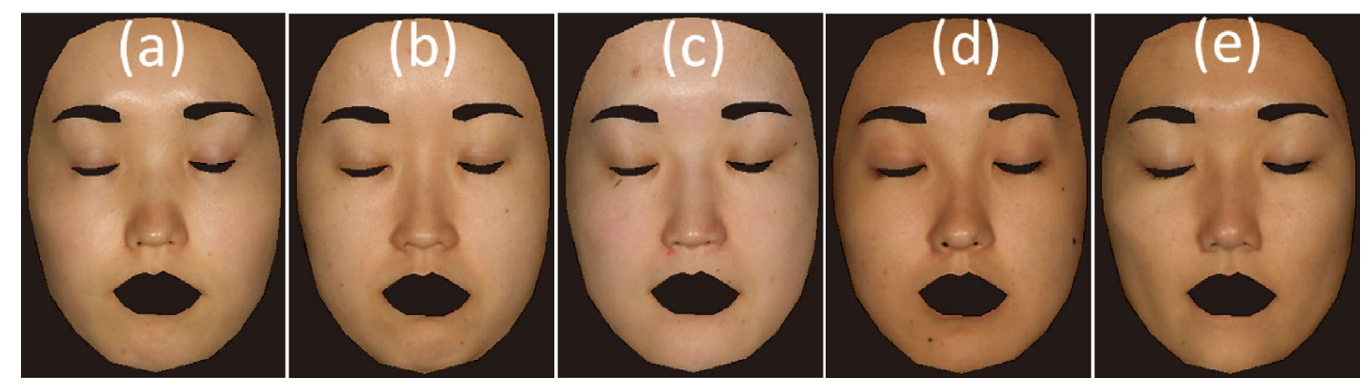

Fig. -8 Evaluated facial images $\left(\mathrm{a}^{-} \mathrm{e}\right)$ that give perceived translucency.

(a)

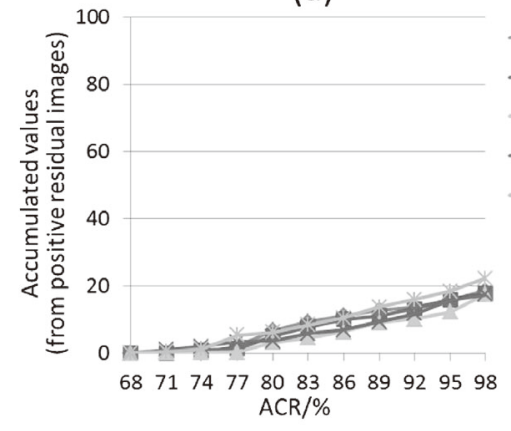

(b)

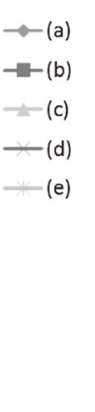

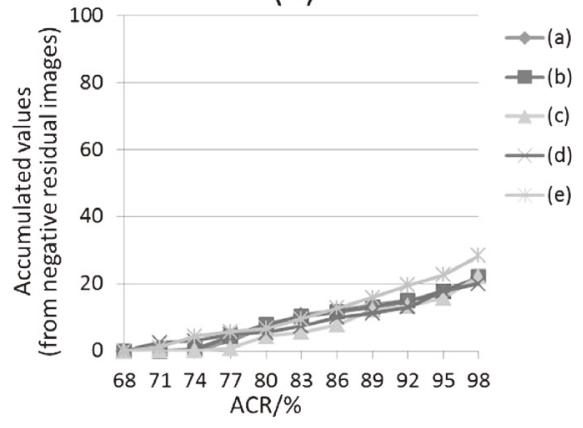

Fig. -9 Transitive curves of accumulated values of the residual images against accumulated cover rate (ACR) standardized at $\mathrm{ACR}=68 \%$.

(a) from the residual images with positive differences, and (b) from the residual images with negative differences. The caption of $\mathrm{a}^{-} \mathrm{e}$ in the graphs denotes the facial images in Fig. -8 .

ここで，式(9)に扔て $\Delta V$ が小さいほど Fig.-8で示し た顔（透明感を感じる 5 名）と類似したレベルの透明感 を有すると予想される。

\section{3. 実験}

2.2.3で得られた予想を受けて, ACR 68\%から ACR 98\%の差分量に着目して，固有差分累積法を用いた透明 

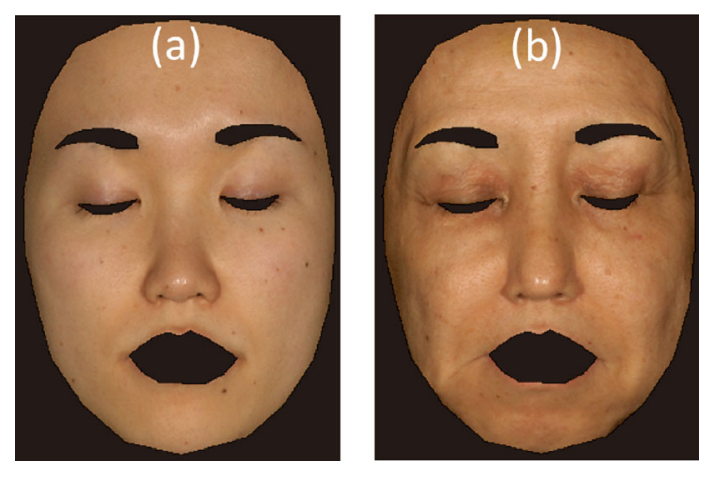

Fig. -10 Test images.

(a) a face with flawless skin, and (b) an aged face with various skin imperfections.

(a)

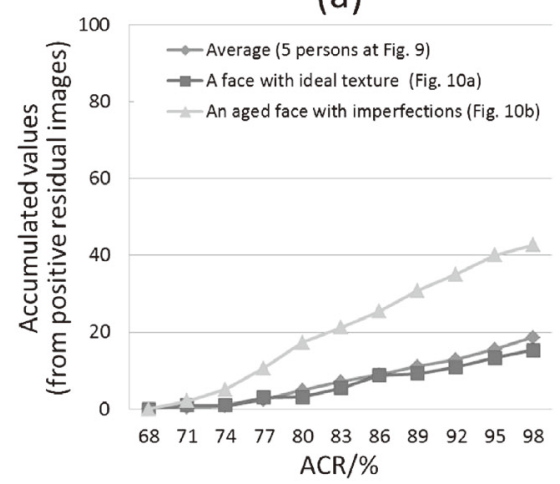

Fig.-11 Transitive curves against ACR.

(a) from the residual images with positive differences, and (b) from the residual images with negative differences.
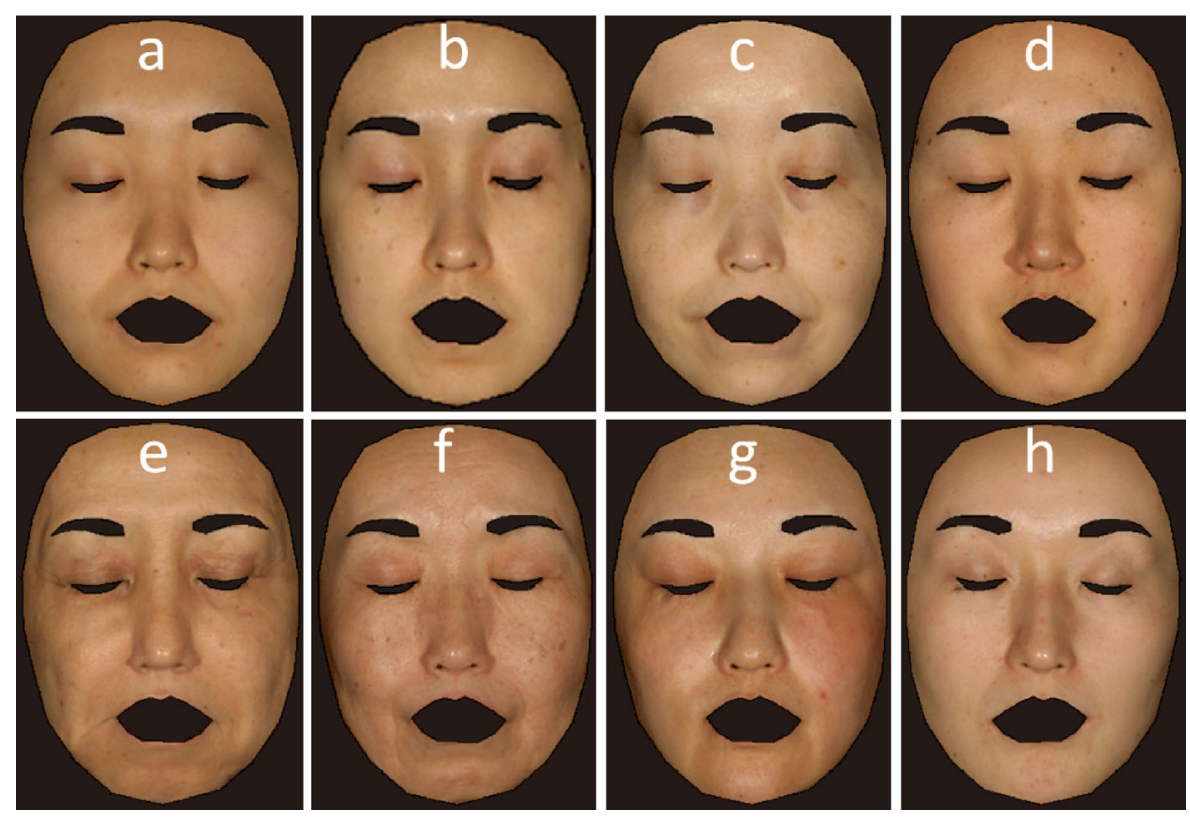

Fig.-12 Example of test facial images for verifying the accuracy of the proposed method (extraction from 14 test images).

Test images were randomly chosen from the MaVIC. 
(a)

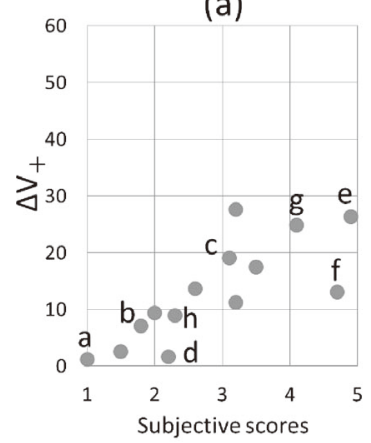

(b)

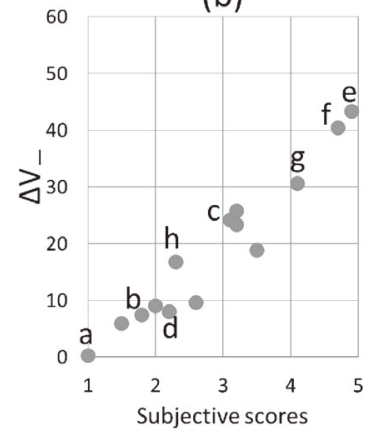

(c)

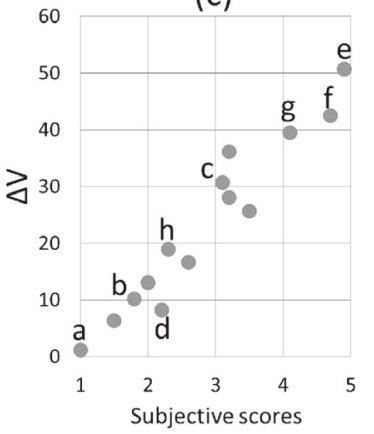

Fig.-13 Relationship between the computed values from the proposed method and scores of subjective evaluation.

(a) $\Delta V_{+}$, (b) $\Delta V_{-}$, and (c) $\Delta V \cdot \Delta V_{+}, \Delta V_{-}$, and $\Delta V$ were computed from the equation (7)-(9). In the figures, the indexes of $\mathrm{a}-\mathrm{h}$ correspond to the facial images of $a^{-} h$ in Fig. -12 .

Step 2 各評価者がそれぞれ以下のスコア基準に従って 各画像について点数づけする：1点（透明感を 感じる), 2 点 (透明感をやや感じる), 3 点 (ど ちらともいえない), 4 点（透明感をやや感じな い), 5 点（透明感を感じない）

Step 3 各画像の点数の平均値を算出し, 各画像の主観 評価による透明感スコアとする

\section{4. 結果および考察}

前章で示した評価手順により得られた透明感スコアと $\Delta V_{+}, \Delta V_{-}$, および $\Delta V$ の関係は Fig. -13 に示したよう に, $\Delta V_{+}$について相関係数 $r=0.79, \Delta V_{-}$について $r=$ $0.97, \Delta V$ について $r=0.96$ といずれも高い相関性を示 した。以上の結果は, 顔テクスチャ特徵量の一般的な定 量化方法として設計した固有差分累積法を ACR 68\% ACR 98\%に適用することで, 透明感を客観的に定量化 できる可能性を示す。また，

・毛穴・色むら，しわなどに由来する $\Delta V_{-}$は $\Delta V_{+}$と比 べてより高い相関性を示す。

・ $\Delta V_{+}$に比べて， $\Delta V_{-}$と主観評価による透明感スコア の関係性（Fig.-13(b)）は， $\Delta V$ と透明感スコアの関 係性（Fig. -13 (c)）に比較的類似している。

以上の結果から， $\Delta V_{-}$を生み出す主要因であるテクス チャ（毛穴・色むら，しわなどの肌の欠点）は，透明感 を阻害する主要因であることが考察された。透明感に関 する先行研究において, しわ, 毛穴, 色むらなど肌の不 均一性・局所的な影を生み出すテクスチヤは透明感を阻 害する重要な要因である可能性が指摘されている20) 222。 このような先行研究の知見と本実験結果の一致は, 提案
法が顔テクスチャの側面から透明感レベルを定量化する 有用な手法である可能性を支持するものと考えられる。

また，本研究結果は，透明感と加齢印象などの他の質 感印象との関連性について今後の研究視点を与える。例 えば，加齢印象の高い Fig.-10（b）の顔画像では，透明 感の高い顔画像と比べて正・負差分量ともに高い值と なっている (Fig.-11(a)，(b))。このうち，透明感を阻害 する主要因と考察された負差分量を生み出す，しわ，毛 穴，色むらといったテクスチャは，加齢要因とも関連す ると考えられる99, 10)。よって, 透明感と加齢印象には負 の相関性がある可能性がある。このような予想を受け て, 今後より多くの顔画像を対象にして, 顔テクスチャ の観点から透明感の阻害要因と, 加齢印象などいくつか の質感印象との関連性を分析・検証することが期待され る。

最後に透明感評価における本研究の今後の課題を考察 する。まず，提案法は顔テクスチャの特徵に着目した手 法であったが, 先行研究ではテクスチャ以外の肌の外観 特徵も透明感に寄与している可能性が指摘されてい

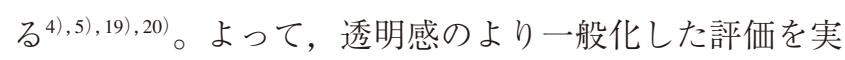
現するには，提案法とあわせて，テクスチャ以外の外観 特徵を定量化できる手法を組み合わせた解析が必要であ り，その中に扔いて提案法を位置づけることが必要であ る。次に, 本研究の主観評価について, 顔テクスチャと 透明感の関連性のみを取り上げ，その相関性が議論され た。しかし，テクスチャは先述のと打り加齢印象など透 明感以外の質感・印象にも寄与している可能性が考えら れる。よって, 透明感以外の質感・印象も含めた主観評 価を行い，様々な質感・印象との関連性の中で，テクス 
チャと透明感の関係を評価し位置づけることが望ましい と考えられる。今後, 提案法を透明感以外の質感・印象 の定量評価にも適用し，この観点を踏まえた検証をして いく必要があると考えられる。

\section{5. 結論}

本研究では, 透明感の定量化を具体的な目標として取 り上げ，全顔を評価対象にした新たな質感・印象評価法 を提案した。提案法は，PCAをべースにした統計的顔 画像解析を応用して, 顔画像のテクスチャ特徵量を選択 的に定量化するものであった。特に, 本法は以下の点に 工夫を設けることで, 従来評価法が達成できなかった解 析を実現できることを論じた。

・化粧評価の目的に特化した質感・印象解析を実現する ため, 統計画像解析を行う際に必要な学習用デー夕と して, 化粧前後の日本人女性の顔画像データのみから 構成された，化粧品評価に必要な情報を多く含む独自 の顔画像データベースを構築したこと

・化粧品研究では顔のテクスチャが議論の対象となるこ とから, 構築した顔画像データベース中の顔形状がす べて統一されテクスチャのみが異なる形状正規化顔画 像データベースを構築したこと

・顔テクスチャの特徵量を抽出するため, 再構成度が異 なる隣接する再構成顔画像間の差分量を求め, これら の差分量を利用して各顔のテクスチャ特徵量を算出し たこと

以上の工夫を組み込んだ固有差分累積法をべースにし て, 評価顔画像のテクスチャ特徵量を透明感が感じられ る顔画像のテクスチャ特徵量と比較することにより, 全 顔を対象にして透明感レベルを定量化できることを示し た。

本論文では，化粧品ユーザの関心が高い透明感を解析 対象として開発法の有用性を論じた。しかし，提案法は 本質的には, テクスチャ特徵が質感・印象を決定する重 要因子であるという考えのもとに，全顔画像のテクス チャ特徵量を抽出するための一般的なアルゴリズムとし て設計されている。よって, 提案法は, 透明感に限らず 顔テクスチヤの特徵に由来する様々な質感・印象の定量 化にも利用が可能であると期待される。今後は, 全顔を 対象にして評価が必要と考えられる透明感以外の様々な 質感・印象（例えば，てかり，立体感，年齢印象など） の定量化に提案法を適用した評価研究も示していきた w。

\section{引用文献}

1) T. Igarashi, K. Nishino, S. K. Nayar, Foundations and Trends in Computer Graphics and Vision, 3(1), 1-95 (2007)

2) M. A. Changizi, W. Zhang, S. Shimojo, Biol. Lett., 2(2), 217-221 (2006)

3）日本化粧品技術者会 編, 化粧品事典, 丸善, 2006, p.217-221

4）五十嵐崇訓, 光学, 43(7), 318-324（2014）

5）五十嵐崇訓，色材協会誌，85(4)，156-163（2012）

6) M. Nomura, R. Hikima, R. Fukuda, Proc. the 26th International Federation of Societies of Cosmetic Chemists (IFSCC) Congress, Buenos Aires, 20-23, 2010

7）山口真美, 柿木隆介 編, 顔を科学する, 東京大学出 版会, 2013, p.307-328

8) T. Layvand, D. Cohen-Or, G. Dror, D. Lischinaki, Proc. SIGGRAPH, 27, 2008

9) C. Arce-Lopera, T. Igarashi, K. Nakao, K. Okajima, Skin Res. Tech., 19(1), 273-278 (2013)

10) C. Arce-Lopera, T. Igarashi, K. Nakao, K. Okajima, Opt. Rev., 19(3), 167-173 (2012)

11）大槻理恵，引間理恵，坂巻 剛，富永昌治，日本色彩 学会誌，37(3)，113-123（2013）

12）藤井 誠，三崎裕子，佐々木一郎，粧技誌，43(2), 72-78 (2009)

13）陳 延偉，独立成分分析法（ICA）のパターン認識・ 画像処理への応用と MATLAB シミュレーション, ト リケップス， 2007

14) W. Zhao, R. Chellappa, P. J. Phillips, A. Rosenfeld, ACM Computing Surveys, 35 (4), 399-458 (2003)

15）五十嵐崇訓，守口順二，瀬尾昌孝，中尾啓輔，陳 延 偉，電子情報通信学会誌 D, J97-D，523-532（2014）

16）五十嵐崇訓，福井貴之，中尾啓輔，陳 延偉，日本顔 学会誌, 13(1)，29-42 (2013)

17）五十嵐崇訓，鈴木敏幸，正木 仁編，化粧品開発の ための美容理論，処方/製剤，機能評価の実際一基 礎 - 応用・最新技術一, 技術教育出版, 2014, p.187196

18) M. Turk, A. Pentland, J. Cognit. Neurosci., 3 (1) , 71-86 (1991)

19）五十嵐崇訓，コスメティックステージ，1(2)，62-68 (2006)

20）征矢智美，野村美佳，林 照次，長谷川敬，粧技誌， 38 (2) , 115-124 (2004)

21) N. Tsumura, R. Usuba, K. Takase, T. Nakaguchi, N. Ojima, N. Komeda, Y. Miyake, Appl. Opt., 47 (35), 6543-6549 (2008)

22）大軽郁子, 吉田那緒子, 日本色彩学会誌，38(3)，162$163(2014)$

23) C. Anitha, M. K. Venkatesha, B. S. Adiga, Int. J. Eng. Sci. 
Tech., 2(10), 5158-5174 (2011)

24) T. Igarashi, T. Fukui, X. Qiao, K. Nakao, A. Kashimoto, K. Fukuda, Y.-W. Chen, Proc. the 25th International Federation of Societies of Cosmetic Chemists (IFSCC) Congress, Barcelona, 145-150, 2008

25) G. Wolberg, Digital Image Warping, IEEE Computer Soci- ety Press, California, 1990

26) T. Igarashi, K. Muta, E. Watarai, M. Seo, K. Tsukamoto, T. Okamoto, Y. W. Chen, Proc. the 2nd Asia Color Association Conference (ACA), Taipei, 86-89, 2014

27）市川伸一，心理測定法への招待，サイエンス社， 1991, p.164-166

\title{
Statistical Facial Image Characterization of Perceived Translucency Based on Principal Component Analysis*
}

\author{
Takanori Igarashi $^{* *, * * *}$, Junji Moriguchi ${ }^{* * *}$, Takahiro Naoki ${ }^{* * *}$, \\ Masataka Seo ${ }^{* * *}$, Yen-Wei Chen ${ }^{* * *}$ \\ Skincare Products Research Laboratory, Kao Corporation **, \\ Graduate School of Information Science and Engineering, Ritsumeikan University ***
}

This study proposes a novel evaluation method for quantifying perceived translucency using statistical facial image analysis. Most conventional evaluation methods for impressions, including perceived translucency, typically use the skin of a certain "part" of the face as representative for evaluation. However, we anticipate that most impressions such as perceived translucency would be recalled from features of the face as a whole, or from various parts of the face (not from one specific area). Therefore, a novel evaluation method that targets images of the entire face should be proposed instead of the conventional methods. In order to develop such a facial image analysis, we employed an image analysis based on principal component analysis (PCA) that is useful for analyzing textural features of the entire face. To begin with, as the learning data necessary for "statistically" extracting the facial textural features, we created a database of shape-normalized facial image data where all of the facial shapes were normalized (unified) and only the facial textures were different. Next, we obtained the eigenspaces that express the textural features of faces using PCA. As the last step, by using the characteristics of eigenspaces, we developed a novel "Eigen residual accumulation method" that would allow us to quantify textural features of faces. The comparative evaluation between the proposed method and subjective assessment for the perceived translucency of faces showed that the method quantifies the level of the translucency with high accuracy.

Key words : face, impression, textural features, perceived translucency, statistical image analysis, principal component analysis, eigenface method, eigenspace, eigen residual accumulation, facial image database, shape normalization 